\title{
Palmitic acid induces neurotoxicity and gliatoxicity in SH-SY5Y human neuroblastoma and T98G human glioblastoma cells
}

\author{
Yee-Wen $\mathrm{Ng}^{1}{ }^{\text {, }}$ Yee-How Say ${ }^{\text {Corresp. } 1}$ \\ ${ }^{1}$ Department of Biomedical Science, Faculty of Science, Universiti Tunku Abdul Rahman (UTAR) Kampar Campus, Kampar, Perak, Malaysia \\ Corresponding Author: Yee-How Say \\ Email address: sayyh@utar.edu.my
}

Background. Obesity-related central nervous system (CNS) pathologies like neuroinflammation and reactive gliosis are associated with high-fat diet (HFD) related elevation of saturated fatty acids like palmitic acid (PA) in neurons and astrocytes of the brain.

Methods. Human neuroblastoma cells SH-SY5Y (as a neuronal model) and human glioblastoma cells T98G (as an astrocytic model), were treated with 100-500 $\mu$ M PA, oleic acid (OA) or lauric acid (LA) for 24 $\mathrm{h}$ or $48 \mathrm{~h}$, and their cell viability was assessed by 3-(4,5-dimetylthiazol-2-yl)-2,5-diphenyltetrazolium bromide (MTT) assay. The effects of stable overexpression of $\gamma$-synuclein ( $\gamma$-syn), a neuronal protein recently recognized as a novel regulator of lipid handling in adipocytes, and transient overexpression of Parkinson's disease (PD) $\alpha$-synuclein [ $\alpha$-syn; wild-type (wt) and its pathogenic mutants A53T, A30P and E46K] in SH-SY5Y and T98G cells, were also evaluated. The effects of co-treatment of PA with paraquat $(P Q)$, a Parkinsonian pesticide, and leptin, a hormone involved in the brain-adipose axis, were also assessed. Cell death mode and cell cycle were analyzed by Annexin V/PI flow cytometry. Reactive oxygen species (ROS) level was determined using 2',7'-dichlorofluorescien diacetate (DCFH-DA) assay and lipid peroxidation level was determined using thiobarbituric acid reactive substances (TBARS) assay.

Results. MTT assay revealed dose- and time-dependent PA cytotoxicity on SH-SY5Y and T98G cells, but not OA and LA. The cytotoxicity was significantly lower in SH-SY5Y- $\gamma$-syn cells, while transient overexpression of wt $\alpha$-syn or its PD mutants (A30P and E46K, but not A53T) modestly (but still significantly) rescued the cytotoxicity of PA in SH-SY5Y and T98G cells. Co-treatment of increasing concentrations of PQ exacerbated PA's neurotoxicity. Pre-treatment of leptin, an anti-apoptotic adipokine, did not successfully rescue SH-SY5Y cells from PA-induced cytotoxicity - suggesting a mechanism of PAinduced leptin resistance. Annexin V/PI flow cytometry analysis revealed PA-induced increase in percentages of cells in annexin V-positive/PI-negative quadrant (early apoptosis) and subG $_{0}-G_{1}$ fraction, accompanied by a decrease in $\mathrm{G}_{2}-\mathrm{M}$ phase cells. The PA-induced ROS production and lipid peroxidation was at greater extent in T98G as compared to that in SH-SY5Y.

Discussion. In conclusion, PA induces apoptosis by increasing oxidative stress in neurons and astrocytes. Taken together, the results suggest that HFD may cause neuronal and astrocytic damage, which indirectly proposes that CNS pathologies involving neuroinflammation and reactive gliosis could be prevented via the diet regimen. 
1 Palmitic acid induces neurotoxicity and gliatoxicity in SH-SY5Y human neuroblastoma

2 and T98G human glioblastoma cells

3

4 Yee-Wen $\mathrm{Ng}^{1}$, Yee-How Say ${ }^{1}$

5 Department of Biomedical Science, Faculty of Science, Universiti Tunku Abdul Rahman

6 (UTAR) Kampar Campus, Kampar, Perak, Malaysia.

7

$8 \quad$ Corresponding author:

9 Yee-How Say ${ }^{1}$

10

11 Email address: sayyh@utar.edu.my

12

13

14

15

16

17

18

19

20

21

22

23 


\section{Abstract}

Background. Obesity-related central nervous system (CNS) pathologies like neuroinflammation and reactive gliosis are associated with high-fat diet (HFD) related elevation of saturated fatty acids like palmitic acid (PA) in neurons and astrocytes of the brain.

Methods. Human neuroblastoma cells SH-SY5Y (as a neuronal model) and human glioblastoma cells T98G (as an astrocytic model), were treated with 100-500 $\mu \mathrm{M}$ PA, oleic acid (OA) or lauric acid (LA) for $24 \mathrm{~h}$ or $48 \mathrm{~h}$, and their cell viability was assessed by 3-(4,5-dimetylthiazol-2-yl)2,5-diphenyltetrazolium bromide (MTT) assay. The effects of stable overexpression of $\gamma$ synuclein ( $\gamma$-syn), a neuronal protein recently recognized as a novel regulator of lipid handling in adipocytes, and transient overexpression of Parkinson's disease (PD) $\alpha$-synuclein [ $\alpha$-syn; wild-type (wt) and its pathogenic mutants A53T, A30P and E46K] in SH-SY5Y and T98G cells, were also evaluated. The effects of co-treatment of PA with paraquat (PQ), a Parkinsonian pesticide, and leptin, a hormone involved in the brain-adipose axis, were also assessed. Cell death mode and cell cycle were analyzed by Annexin V/PI flow cytometry. Reactive oxygen species (ROS) level was determined using 2',7'-dichlorofluorescien diacetate (DCFH-DA) assay and lipid peroxidation level was determined using thiobarbituric acid reactive substances (TBARS) assay.

Results. MTT assay revealed dose- and time-dependent PA cytotoxicity on SH-SY5Y and T98G cells, but not OA and LA. The cytotoxicity was significantly lower in SH-SY5Y- $\gamma$-syn cells, while transient overexpression of wt $\alpha$-syn or its PD mutants (A30P and E46K, but not A53T) modestly (but still significantly) rescued the cytotoxicity of PA in SH-SY5Y and T98G cells. 
47 Co-treatment of increasing concentrations of PQ exacerbated PA's neurotoxicity. Pre-treatment 48 of leptin, an anti-apoptotic adipokine, did not successfully rescue SH-SY5Y cells from PA49 induced cytotoxicity - suggesting a mechanism of PA-induced leptin resistance. Annexin V/PI 50 flow cytometry analysis revealed PA-induced increase in percentages of cells in annexin V51 positive/PI-negative quadrant (early apoptosis) and $\mathrm{subG}_{0}-\mathrm{G}_{1}$ fraction, accompanied by a 52 decrease in $\mathrm{G}_{2}-\mathrm{M}$ phase cells. The PA-induced ROS production and lipid peroxidation was at 53 greater extent in T98G as compared to that in SH-SY5Y.

54 Discussion. In conclusion, PA induces apoptosis by increasing oxidative stress in neurons and astrocytes. Taken together, the results suggest that HFD may cause neuronal and astrocytic damage, which indirectly proposes that CNS pathologies involving neuroinflammation and reactive gliosis could be prevented via the diet regimen. 


\section{Introduction}

77 Obesity is now a global health issue that presents a major risk for serious diet-related 78 noncommunicable diseases including diabetes mellitus, cardiovascular diseases, hypertension, stroke, and some cancers (World Health Organization, 2018). High-fat diet (HFD) rich in

80 saturated fatty acids (SFAs) has long been recognised to contribute to many adverse metabolic

81 health issues. In the past two decades, it was found that HFD-induced obesity has been 82 associated with neuroinflammation and reactive gliosis (Dorfman \& Thaler, 2015), leading to

83 CNS pathologies such as neurodegenerative diseases (Guillemot-Legris and Muccioli, 2017). A

84 case-control study demonstrated a link between the intake of fat from animal sources rich in SFA

85 and PD (Logroscino et al., 1996). Several prospective studies also showed association of body

86 mass index (BMI) with increased risk of Alzheimer's disease (Gustafson et al., 2003) and PD

87 (Hu et al., 2006); and on the contrary, lower BMI is associated with lower risk of PD (Sääksjärvi

88 et al., 2014). Furthermore, the first study in humans using positron emission tomography with

$89\left[{ }^{11} \mathrm{C}\right]$-palmitate and $\left[{ }^{18} \mathrm{~F}\right]$ fluoro-6-thia-heptadecanoic acid showed increased fatty acid (FA)

90 uptake and accumulation in the brain of obese subjects with metabolic syndrome (Karmi et al.,

91 2010). This suggests that FAs are able to cross the blood-brain-barrier and are able to be taken up 
92 by brain cells. In fact, peripheral FAs were shown to have relationship with central FAs, as

93 reported by a study done on human whole blood and cerebrospinal fluid (Guest et al., 2013).

94

95 PA, a long chain 16:0 SFA, is the most common FA found in animals and plants such as palm oil,

96

97

98

palm kernel oil, butter, cheese, milk and meat (Gunstone et al., 2010). Despite its crucial biological functions such as energy storage, acting as a signalling molecule and maintaining integrity of cellular membranes (Gunstone et al., 2010), PA has been found to be increased in diseased brains. Particularly, PA level appeared to be increased in the frontal cortex lipid rafts in PD (Fabelo et al., 2011); and in parietal cortex in AD (Fraser et al., 2010). Furthermore, PA was found to cause lipotoxicity to several cell lines in vitro. For instance, PA triggered the release of tumour necrosis factor- $\alpha$ and interleukin-6, activating inflammatory signalling in astrocytes (Gupta et al., 2012). PA also induced apoptosis in human hepatoma cell line, HepG2 (Zhang et al., 2004), neural progenitor cells (Park et al., 2011) and neuronal cell line, SH-SY5Y (Hsiao et al., 2014).

Other than neurons, the brain also comprises and depends on surrounding non-neuronal cells such as glial, epithelial cells, pericytes and endothelia, for them to function correctly (FreireRegatillo et al., 2017). Glial cells were once thought of to serve as a supportive system for neurons. Now they are found to possess modulatory, trophic and immune functions in the brain (Gupta et al., 2012). Astrocyte is a type of glial cell, which is the most plentiful and varied nonneuronal cell in the CNS (Argente-arizón et al., 2015). Of note, marked astrogliosis was observed in the hypothalamus of HFD-induced or genetically obese mice (Buckman et al., 2013), suggesting that astrocyte plays a role in reactive gliosis leading to CNS pathologies. 
116 A family of neuronal proteins that are implicated in both obesity and $\mathrm{CN}$ pathologies is the 117 synucleins, i.e., $\alpha$ - and $\gamma$-synucleins ( $\alpha$-syn, $\gamma$-syn). They are small, soluble, highly conserved 118 proteins, predominantly expressed in the neurons. $\alpha$-syn is a major component of Lewy bodies 119 and Lewy neurites appearing in the postmortem brain of PD and other synucleinopathies 120 (Spillantini \& Goedert, 2000). Genetic mutations in $\alpha$-syn, including point mutations - A53T, 121 A30P and E46K, have been linked to familial PD (Polymeropoulos et al., 1997). Neuronal 122 expression of either human wild-type (wt) or PD-related mutant $\alpha$-syn induces 123 neurodegeneration associated with pathological accumulations of $\alpha$-syn. Previous studies also 124 revealed that $\alpha$-syn-containing inclusion bodies were present in astrocytes of sporadic PD 125 (Wakabayashi et al., 2000; Braak et al., 2007) and overexpression of wt $\alpha$-syn in U373 astrocytoma cells induces of astroglial apoptotic cell death (Stefanova et al., 2001). Moreover $\alpha$ syn and $\gamma$-syn were found to affect lipid uptake and metabolism in brain and adipocytes 128 (Golovko et al., 2005; Millership et al., 2013; Hsiao et al., 2017).

Given the involvement of FAs particularly PA in CNS pathologies and the possible role of $\alpha$-syn and $\gamma$-syn in modulating the effects of FAs, therefore, the objective of this study was to first evaluate the effects of PA, oleic acid (OA; long chain FA with lipid number of C18:1 cis-9 and a major constituent in plant oil such as olive oil, almond oil, pecan oil and canola oil) and lauric acid (LA; medium chain 12:0 SFA which comprises about 50\% of FA content in coconut oil, coconut milk, laurel oil and palm kernel oil) on the viability of human neuroblastoma SH-SY5Y and human glioblastoma T98G cell lines. SH-SY5Y cells were selected for the experiments as 137 they have been widely used as a cell model of dopaminergic neurons for PD research (Xie et al., 
138 2010), while T98G cells were selected due to its biological resemblance with primary astrocytes

139 and its broad use in research as an astrocyte cell model (Avila Rodriguez et al., 2014; Cabezas et

140 al., 2015; Avila-Rodriguez et al., 2016). The effects of stable overexpression of $\gamma$-syn in SH-

141 SY5Y and transient overexpression of $\alpha$-syn (wt and PD mutants A53T, A30P and E46K) in SH-

142 SY5Y and T98G cells were also evaluated. We found that PA is neurotoxic and gliatoxic to SH-

143 SY5Y and T98G cells, respectively. To investigate the potential synergistic effect of 144 environmental factors for dopaminergic neurotoxicity, SH-SY5Y cells were co-treated with PA 145 (to mimic HFD exposure), and increasing concentrations of paraquat (PQ), a herbicide that is 146 implicated in the development of PD (Pezzoli and Cereda, 2013). Since leptin, a hormone that is 147 involved in the brain-adipose axis, has been shown to have neuroprotective effect in SH-SY5Y 148 cells (Russo et al., 2004; Lu et al., 2006; Weng et al., 2007), we also investigated whether leptin 149 pre-treatment could rescue SH-SY5Y cells from PA neurotoxicity. The mode of cell death 150 induction by PA in SH-SY5Y and T98G was investigated using Annexin V/PI staining followed 151 by flow cytometry analysis. Lastly, to attribute whether apoptotic cell death is caused by 152 oxidative stress, intracellular ROS and extent of lipid peroxidation (TBARS level) were assessed.

\section{Materials and methods}

155

156

157

158

159 160

\subsection{Cell culture, transfections and treatments}

SH-SY5Y (ATCC ${ }^{\circledR}$ CRL-2266 ${ }^{\mathrm{TM}}$ ) and T98G (ATCC ${ }^{\circledR}$ CRL-1690 ${ }^{\mathrm{TM}}$ ), obtained from the American Type Culture Collection (ATCC), were maintained in Eagle's Minimum Essential Medium (MEM) (Corning, NY, USA) and Dulbecco's Modified Eagle's Medium (DMEM) (Corning, NY, USA), respectively, supplemented with $10 \%(\mathrm{v} / \mathrm{v})$ fetal bovine serum (SigmaAldrich, MO, USA) and 1\% (v/v) penicillin-streptomycin (Nacalai Tesque, Japan) at $37^{\circ} \mathrm{C}$ and 
161 162

3

$5 \% \mathrm{CO}_{2}$ in air. All cell lines have been checked to ensure they are free of contamination and have been used from young stock (less than 7 passages). SH-SY5Y overexpressing $\gamma$-Syn (SHSY5Y- $\gamma$ ) was established by stable transfection of SH-SY5Y cells with plasmid pOTB7 carrying full length human $\gamma$-syn (accession number: BC014098) cDNA (clone ID: 4546444; obtained from Addgene, MA, USA). Transfection was performed by electroporation using ECM $^{\circledR} 830$ ElectroSquarePorator $^{\mathrm{TM}}$ (BTX Harvard Apparatus, Holliston, MA) and cells were cultured in complete growth medium for $72 \mathrm{~h}$ prior to 14 days of antibiotic selection with $1 \mathrm{mg} / \mathrm{ml}$ of G418 sulfate (A.G. Scientific Inc., USA). Following that, $\gamma$-syn protein expression was assessed by Western blot using anti- $\gamma$-synuclein primary antibody, clone EP1539Y (Millipore, USA) prepared in 1:5000 dilution and secondary HRP-conjugated anti-rabbit IgG antibody (Sigma Aldrich, USA) prepared in 1:10000 dilution (data shown in raw data file link as stated in 'Data Availability').

Transient transfection of $\alpha$-syn (wt, PD mutants A53T, A30P or E46K) cDNAs (Choong \& Say, 2011) or $\gamma$-Syn cDNA was performed in 96 -well plates using TurboFect ${ }^{\mathrm{TM}}$ Transfection Reagent (Cat. No.: R0531; Thermo Fisher Scientific, CA, USA) according to the manufacturer's protocol.

The FA-bovine serum albumin complex was prepared according to the protocols established by Hsiao et al., (2014), albeit with slight modification. Briefly, $20 \mathrm{mM}$ of FA was prepared in 0.01 $\mathrm{N}$ sodium hydroxide in a dry bath of $80^{\circ} \mathrm{C}$. MEM or DMEM with $1 \%$ BSA was added to different volumes of FA stock solution to reach final concentrations of 100 to $500 \mu \mathrm{M}$. The mixtures were incubated in the $37^{\circ} \mathrm{C}$ water bath for 30 min before being treatment of cell lines. The cell lines were first treated with increasing concentrations $(0,100,200,300,400$ and 500 
184

185

186

187

188

189

190

191

192

193

194

195

196

197

198

199

200

201

202

203

204

205

206

$\mu \mathrm{M})$ of PA (Merck, USA), OA (Nacalai Tesque, Japan) or LA (Merck, USA) to determine the cytotoxicity of various FAs. The untreated $(0 \mu \mathrm{M})$ consisted of MEM or DMEM with 1\% BSA. After that, different concentrations were used for different assays as described in the following sections.

\subsection{MTT cell viability assay}

SH-SY5Y/SH-SY5Y- $\gamma\left(1.2 \times 10^{4}\right.$ cells/well $)$ or T98G $\left(8 \times 10^{3}\right.$ cells/well $)$ cells were seeded into 96-well plates, treated with different treatment paradigms and incubated for 24 or $48 \mathrm{~h}$. Medium with vehicle (BSA) was used as blank. Then, $20 \mu \mathrm{l}$ of $5 \mathrm{mg} / \mathrm{ml} \mathrm{3-(4,5-dimethylthiazol-2-yl)-2,5-}$ diphenyltetrazolium bromide (MTT, Bio Basic Inc., Canada) prepared in phosphate buffer saline (PBS), was added to each well and the plate was incubated at $37^{\circ} \mathrm{C}$ for $4 \mathrm{~h}$. The medium in each well was then discarded and $100 \mu 1$ of dimethyl sulfoxide (DMSO) was added into each well. The plate was incubated at $37^{\circ} \mathrm{C}$ for 30 min prior to absorbance reading at $560 \mathrm{~nm}$ using FLUOstar $^{\circledR}$ Omega Microplate Reader (BMG LABTECH, Germany).

\subsection{Cell death mode and cell cycle analyses by flow cytometry}

The cell death mode of SH-SY5Y and T98G cell lines induced by PA was determined using flow cytometry. The cells were stained with annexin V and PI using Alexa Fluor ${ }^{\circledR} 488$ Annexin V/Dead Cell Apoptosis Kit (Cat. No.: V13241; Thermo Fisher Scientific, CA, USA). The assay was performed according to the manufacturer's protocol. Briefly, the untreated and treated cells were trypsinised, collected and washed with PBS. Then, the cells were pelleted at $800 \mathrm{~g}$ for 5 min. The cells were resuspended at the density of $1 \times 10^{6}$ cells $/ \mathrm{ml}$ with $1 \times$ annexin-binding buffer. To every $100 \mu 1$ of cell suspension, $5 \mu$ of Alexa Fluor ${ }^{\circledR} 488$ annexin V and $1 \mu 1$ of 100 
$207 \mu \mathrm{g} / \mathrm{ml}$ PI (prepared by adding $5 \mu \mathrm{l}$ of $1 \mathrm{mg} / \mathrm{ml}$ stock to $45 \mu \mathrm{l}$ of $1 \times$ annexin-binding buffer) were 208 added. The cells were incubated at room temperature for $15 \mathrm{~min}$. After that, $400 \mu \mathrm{l}$ of $1 \times$ 209 annexin-binding buffer was added and the cells were analysed immediately using Attune ${ }^{\mathrm{TM}} \mathrm{Nxt}$ 210 Flow Cytometer (Thermo Fisher Scientific, CA, USA). Alexa Fluor ${ }^{\circledR} 488$ annexin V and PI 211 fluorescence emission was measured using the 530/30 nm (BL1) and 695/40 nm (BL3) emission 212 filters, respectively, with excitation at $488 \mathrm{~nm}$. A total of 10,000 events per sample was recorded. 213 Data collected were analysed with Attune ${ }^{\mathrm{TM}}$ Nxt Software. Compensation was set up using 214 unstained cells, cells stained with Alexa Fluor ${ }^{\circledR} 488$ annexin V only and cells stained with PI 215 only. Negative gating strategy involving forward scatter $v s$. side scatter plot was to eliminate cell 216 debris.

218 Cell cycle analysis was performed according to Henry et al. (2013) with slight modification. 219 Briefly, untreated and treated cells were harvested and washed with PBS. The cells were then 220 fixed with $1 \mathrm{ml} 70 \%$ ethanol at $-20^{\circ} \mathrm{C}$ for $1 \mathrm{~h}$. After that, the cells were centrifuged at $2500 \mathrm{~g}$ for

$2215 \mathrm{~min}$ and the supernatant was discarded. The pellet was resuspended with $1 \mathrm{ml}$ phosphate-citrate 222 wash buffer [200 mM Na $2 \mathrm{PO}_{4}$ (Merck, USA), $100 \mathrm{mM}$ citric acid (Merck, USA)] followed by

223 centrifugation at $2500 \mathrm{~g}$ for $5 \mathrm{~min}$. The supernatant was discarded and the cell pellet was resuspended in PI staining solution containing $10 \mu \mathrm{g} / \mathrm{ml}$ PI and $100 \mu \mathrm{g} / \mathrm{ml} \mathrm{RNase} \mathrm{A} \mathrm{prepared} \mathrm{in}$ PBS. The cells were analysed using the Attune ${ }^{\mathrm{TM}}$ Nxt Flow Cytometer with the 695/40nm (BL3) emission filter. The data collected were analysed using Attune ${ }^{\mathrm{TM}}$ Nxt Software.

\subsection{Intracellular ROS quantification by DCFH-DA assay}

Intracellular ROS level was detected using the fluorescent probe DCFH-DA (Sigma-Aldrich, 
230 MO). SH-SY5Y or T98G cell line was seeded with phenol red-free complete medium in black

231 96-well plates overnight, and $25 \mu \mathrm{M}$ DCFH-DA prepared in complete medium was added into

232 each well. The cells were incubated at $37^{\circ} \mathrm{C}$ for $45 \mathrm{~min}$ before the medium was removed from

233 each well. Next, $100 \mu \mathrm{l}$ of FA treatment was added and the plate was incubated at $37^{\circ} \mathrm{C}$ for $6 \mathrm{~h}$.

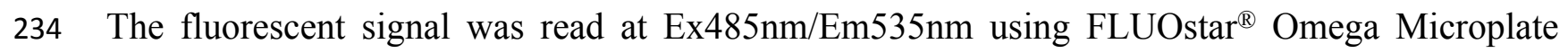

235 Reader (BMG LABTECH, Germany). Untreated, unstained cells were used as blank.

236

$237 \quad 2.5 \quad$ Quantification of lipid peroxidation using TBARS assay

238 Parameter ${ }^{\mathrm{TM}}$ TBARS Assay kit (R\&D Systems, MN, USA) was used to quantify lipid

239

240

241

242

243

244

245

246

247

248

249

250

251

252

peroxidation by measuring TBARS levels, as an indicator of oxidative stress in cells. The assay was performed in SH-SY5Y and T98G cells after PA treatment, according to the manufacturer's

protocol. Briefly, cell lysate was prepared by first collecting the cells and washing the cells with cold PBS. Then, the cells were resuspended in deionised water at the density of $1 \times 10^{6} \mathrm{cells} / \mathrm{ml}$. The cell suspension was subjected to a total of 3 cycles of 10 -second sonication and then freeze/thaw at $\leq-20^{\circ} \mathrm{C}$. Then, $300 \mu$ of the cell lysate was subjected to acid treatment with 300 $\mu l$ of TBARS Acid Reagent provided in the kit. After 15 min of incubation at room temperature, the mixture was centrifuged at $\geq 12000 \mathrm{~g}$ for $4 \mathrm{~min}$ and the supernatant was retained. Next, $150 \mu 1$ of standards and samples were added into each well of the microplate and $75 \mu 1$ of TBA Reagent was added. The optical density of each well was pre-read at $532 \mathrm{~nm}$ using FLUOstar ${ }^{\circledR}$ Omega Microplate Reader (BMG LABTECH, Germany). Then, the microplate was covered with the adhesive strip provided and was incubated at $45-50^{\circ} \mathrm{C}$ for $2-3 \mathrm{~h}$. After incubation, the optical density was read at $523 \mathrm{~nm}$. The pre-reading was subtracted from the final reading to correct for the samples contribution to the final absorption at $532 \mathrm{~nm}$. The results were calculated according 
253 to the manufacturer's instruction. A linear standard curve was plotted and the concentrations of

254 samples were read from the standard curve and were multiplied by the dilution factor 2.

255

$256 \quad 2.6 \quad$ Statistical Analysis

257 Quantitative data were presented as mean \pm standard error of mean (S.E.M.) from triplicates of 258 three independent experiments, unless otherwise stated. Statistical analysis was performed using 259 Statistical Package for the Social Sciences (SPSS) software (version 23.0). (SPSS Inc., IL). All 260 results were subjected to paired-sample $t$ - test. A $p$-value of $<0.05$ was considered as statistically 261 significant.

262

\section{$263 \quad 3 . \quad$ Results}

\subsection{PA, but not $\mathrm{OA}$ and $\mathrm{LA}$, is neurotoxic and gliatoxic}

Generally, PA induced cytotoxicity towards SH-SY5Y and SH-SY5Y- $\gamma$ in a time- and dosedependent manner at concentrations above $300 \mu \mathrm{M}$ at $24 \mathrm{~h}$, and at concentrations above $200 \mu \mathrm{M}$ at $48 \mathrm{~h}$. Figures $1 \mathrm{~A}$ and B show the effect of PA treatment on the cell lines for 24 and $48 \mathrm{~h}$. At $24 \mathrm{~h}$, the percentage of viable cells decreased dramatically at PA concentrations $\geq 300 \mu \mathrm{M}$, while at $48 \mathrm{~h}$, the cell viability decreased drastically at PA concentrations $\geq 200 \mu \mathrm{M}$. Except at $500 \mu \mathrm{M}$, the viability of SH-SY5Y- $\gamma$ cells was significantly higher than SH-SY5Y cells at concentrations $\geq 300 \mu \mathrm{M}(24 \mathrm{~h})$ and at concentrations $\geq 200 \mu \mathrm{M}(48 \mathrm{~h})$. The concentrations of $50 \%$ cytotoxicity $272\left(\mathrm{LC}_{50}\right)$ for SH-SY5Y and SH-SY5Y- $\gamma$ were 420 and $440 \mu \mathrm{M}$, respectively, at $24 \mathrm{~h}$, and 320 and $273380 \mu \mathrm{M}$, respectively, at $48 \mathrm{~h}$. At lower concentrations, PA did not cause cytotoxicity but 274 promoted the viability of SH-SY5Y- $\gamma$ instead at $48 \mathrm{~h}$. 
276 The treatment of OA for 24 and $48 \mathrm{~h}$ generally increased the cell viability in both SH-SY5Y and

277 SH-SY5Y- $\gamma$, as shown in Figures 1C and D. The cell viability increased as a function of OA

278 concentration and reached the peak of $\sim 140 \%$ at $400 \mu \mathrm{M}$ and $300 \mu \mathrm{M}$ OA for SH-SY5Y and SH-

279 SY5Y- $\gamma$, respectively. For the treatment of LA, the cell viability of SH-SY5Y, but not that of

$280 \mathrm{SH}-\mathrm{SY} 5 \mathrm{Y}-\gamma$, was generally increased, as shown in Figures $1 \mathrm{E}$ and F. The results indicate that LA

281 promoted the viability of SH-SY5Y but had no effect on SH-SY5Y- $\gamma$ at concentrations $<300$

$282 \mu \mathrm{M}$ and exerted significant decrease in cell viability (8-18\%) at $\geq 400 \mu \mathrm{M}$ at $48 \mathrm{~h}$.

283

284

285

286

287

288

289

290

291

292

293

294

295

296

297 298

Similar with SH-SY5Y cells, PA at lower concentrations $(<200 \mu \mathrm{M})$, increased the viability of astrocytic T98G cells, and while at higher concentrations $(\geq 200 \mu \mathrm{M})$, reduced the cell viability significantly, in a dose-dependent manner (Figure 1G). The $\mathrm{LC}_{50}$ of PA in T98G cells was 320 $\mu \mathrm{M}$. Like in SH-SY5Y cells, OA also increased the cell viability of T98G at concentrations $\geq$ $200 \mu \mathrm{M}$, while LA did not affect the cell viability significantly (Figure 1G).

3.2 Co-treatment of PQ exacerbates neurotoxicity of PA, but leptin did not ameliorate

\section{the neurotoxicity of PA}

Co-treatment of PQ exacerbates the neurotoxicity of PA in a dose-dependent manner, as illustrated in Figure 1H. At $200 \mu \mathrm{M}$ PQ, the cell viability decreased to $41.6 \pm 1.2 \%$ (Figure $1 \mathrm{H}$ ). As compared to PQ treatment alone, the $\mathrm{LC}_{50}$ was determined to be $380 \mu \mathrm{M}$ (data shown in raw data file link as stated in 'Data Availability'). Interestingly, pre-treatment of increasing concentrations of leptin for $6 \mathrm{~h}$ not only did not rescue the cells from PA neurotoxicity, but further exacerbates PA neurotoxicity at concentrations $\geq 40 \mu \mathrm{g} / \mathrm{ml}$ (Figure 1I). 


\section{$299 \quad 3.3 \quad$ Transient transfection of $\alpha$-syn and its PD mutants led to modest rescue from the}

300

301

302

303

304

305

306

307

308

309

310

311

312

313

314

315

316

317

318

319

320

321

\section{neurotoxicity of PA}

To investigate the gene-environment interaction in affecting neurotoxicity and gliatoxicity, SHSY5Y and T98G cells were transiently transfected with wt, A30P, E46K or A30P $\alpha$-syn for $48 \mathrm{~h}$ before further treated with $\mathrm{LC}_{50}$ of PA (320 $\mu \mathrm{M}$ for both SH-SY5Y and T98G cells). Instead of exacerbating the cytotoxic effect of PA, transient overexpression of wt $\alpha$-syn or its PD mutants (A30P and E46K, but not A53T) significantly rescued SH-SY5Y cells from the toxicity of PA, by increasing their viability to up to $10 \%$ (Figure $2 \mathrm{~A}$ ). The similar phenomenon could also be observed in T98G cells, where transient overexpression of A30P and E46K significantly increased the cell viability to around $10 \%$, compared with the untransfected cells treated with PA (Figure 2B). Furthermore, transient overexpression of wt, A30P or E46K $\alpha$-syn also increased the viability of SH-SY5Y cells (but not T98G) to up to $20 \%$ when subjected to OA treatment (Figure 2A).

Since the discrepancy in the cytotoxic effect of $\alpha$-syn overexpression might be due to the transfection method used (transient in this study vs. stable in Stefanova et al., 2001), we investigated whether the neurotoxicity results of PA in stable SH-SY5Y- $\gamma$ cells could be replicated by transient transfection of $\gamma$-syn in SH-SY5Y and T98G cells. Indeed, transient transfection of $\gamma$-syn did not significantly increase the cell viability of SH-SY5Y cells when subjected to PA treatment (compared with results in Figure 1B). In short, transient transfection of $\alpha$-syn or $\gamma$-syn will have different effects in SH-SY5Y or T98 cells compared with stable transfection. 


\section{$322 \quad 3.4 \quad$ PA induces neurotoxicity and gliatoxicity via apoptotic cell death}

323 To investigate the mode of cell death induced by PA in SH-SH5Y and T98G cells, dual staining

324 with Annexin V and PI was performed and cells were analysed by flow cytometry. The results

325 showed that PA at lower concentrations did not induce apoptosis in SH-SY5Y cells (less than

$32620 \%$ cells undergoing apoptosis) and T98G cells (less than 5\% cells undergoing apoptosis), but

327 at $300 \mu \mathrm{M}$, PA significantly increased the percentage of apoptotic cells to about 2 fold in both

328 cell lines (Figures 3A, B and E). Single staining with PI for cell cycle analysis by flow cytometry 329 also revealed that DNA fragmentation was statistically significant in $200 \mu \mathrm{M}$ and $300 \mu \mathrm{M}$ PA330 treated SH-SY5Y and T98G cells (Figures 3C, D and F). For SH-SY5Y cells, the increment in 331 the percentage of DNA fragmentation as indicated by the R1 gate was 1.3 -fold $(22.56 \pm 0.53 \%$ to $33228.23 \pm 0.03 \%$ ) and 2.6 -fold (from $22.56 \pm 0.53 \%$ to $57.75 \pm 0.19 \%$ ) for $200 \mu \mathrm{M}$ and $300 \mu \mathrm{M}$ 333 PA treatments, respectively (Figure 3F). While for T98G, the increment was 1.5-fold (from 6.74 $334 \pm 0.17 \%$ to $10.26 \pm 0.22 \%$ ) and 4.1 -fold (from $6.74 \pm 0.17 \%$ to $27.66 \pm 0.35 \%$ ) for $200 \mu \mathrm{M}$ and $335300 \mu \mathrm{M}$ PA treatments, respectively (Figure 3F). These were associated with the decrease in cell 336 percentages in the other cell cycle phases.

\subsection{PA induces apoptotic cell death in SH-SY5Y and T98G cells via oxidative stress}

To attribute whether apoptotic cell death induction by PA in SH-SY5Y and T98G is caused by oxidative stress, intracellular $\operatorname{ROS}\left(\mathrm{H}_{2} \mathrm{O}_{2}\right)$ and extent of lipid peroxidation (TBARS level) were assessed. PA and OA treatments both increased ROS levels in a dose-dependent manner in both SH-SY5Y and T98G cells, with PA inducing greater ROS generation as compared to OA (Figure 4). PA-induced ROS production was at greater extent in T98G (5.39 \pm 0.31 -fold $)$ as compared to that in SH-SY5Y $(2.83 \pm 0.16$-fold $)$ at $500 \mu \mathrm{M}$ PA treatment. OA also elevated the level of ROS 
345 in both cell lines but to a degree lesser than PA, except $500 \mu \mathrm{M}$ OA in SH-SY5Y. However, the 346 changes in the lipid peroxidation level were not dose- and time-dependent in both cell lines, as

347 shown in Figure 4. In SH-SY5Y, the level of lipid peroxidation increased 0.3-fold to 1.3-fold at $34824 \mathrm{~h}$ at 100 and $300 \mu \mathrm{M}$ PA treatments. At $200 \mu \mathrm{M}$, the fold change decreased to 0.5 -fold as 349 compared to the untreated. For the $48 \mathrm{~h}$ treatment of PA, the level of lipid peroxidation decreased 350 gradually to 0.7 -fold of the untreated at 100 and $200 \mu \mathrm{M}$, and to 0.5 -fold at $300 \mu \mathrm{M}$. In T98G, 24 $351 \mathrm{~h}$ treatment of PA increased the level of lipid peroxidation to 1.5- and 1.4- fold at 100 and 300 $352 \mu \mathrm{M}$, respectively, as compared to the untreated. $200 \mu \mathrm{M}$ PA decreased the level to 0.8 -fold. At $35348 \mathrm{~h}, \mathrm{PA}$ treatment on the cell line increased the lipid peroxidation level to 1.3-, 1.1- and 1.8-fold 354 of that of the untreated at 100, 200 and $300 \mu \mathrm{M}$, respectively. In short, $300 \mu \mathrm{M}$ of PA treatment 355 impacted the lipid peroxidation level the most. The changes of lipid peroxidation level in SH356 SY5Y were lesser as compared to that of T98G, in which the latter fold change was increased to 357 1.9-fold at $300 \mu \mathrm{M}$ after $48 \mathrm{~h}$ of PA treatment.

358

\section{Discussion}

360

361

362

363

364

365

366

367

MTT assay results revealed that only PA, but not OA and LA, is cytotoxic to all of the three cell lines namely, SH-SY5Y, SH-SY5Y- $\gamma$ and T98G. The range of FA concentrations used was within the physiological range of circulating free FAs in human plasma, which is $\sim 0.1-1.0 \mathrm{mM}$ (Yuan et al., 2013). The rate of PA $\beta$-oxidation was also found to increase as a function of PA concentration, from $15 \mu \mathrm{M}$ to $2 \mathrm{mM}$, and peaked at $200 \mu \mathrm{M}$, in homogenates of astrocytes cultured from neonatal mouse brain (Murphy et al., 1992). The similar range of FA concentrations had been used in many studies, and the cytotoxic effect of PA observed was also similar to that reported earlier (Gupta et al., 2012; Yuan et al., 2013; Hsiao et al., 2014). Dose- 
368 and time-dependent apoptotic effects were observed in SH-SY5Y after PA treatment (Kim et al.,

369 2011). Further elucidation of pathways leading to PA-induced apoptosis revealed that

370 endoplasmic reticulum (ER) stress, as indicated by the expression of spliced X-box binding

371 protein 1 mRNA and immunoglobin heavy chain-binding protein, was involved (Kim et al.,

372 2011). In addition, PA inactivated 5' adenosine monophosphate-activated protein kinase

373 (AMPK), and re-activation of AMPK by N1-( $\beta$-D-Ribofuranosyl)-5-aminoimidazole-4-

374 carboxamide, ameliorated PA-induced cytotoxicity with diminished ER stress-mediated

375 apoptosis (Kim et al., 2011). Correspondingly, Hsiao et al. (2014) also showed that PA triggered

$376 \mathrm{SH}-\mathrm{SY} 5 \mathrm{Y}$ apoptotic cell death via protein palmitoylation, which induced $\mathrm{G}_{2} / \mathrm{M}$ cell

377 cycle arrest and ER stress.

378

379 On the other hand, OA was shown to promote the cell growth in both neuronal SH-SY5Y and 380 astrocytic T98G cell lines, parallel to previous studies in which OA was found to have neuroprotective and neurotrophic effects. For example, OA was found to be superior to

382 383 docosahexaenoic acid or linoleic acid in the protection of mouse neuroblastoma Neuro-2a and primary rat cortical neurons against PA- or ceramide-induced cytotoxicity (Kwon et al., 2014). OA pre-treatment attenuated PA-induced mitochondrial dysfunction and insulin resistance by inhibiting the phosphorylation of mitogen-activated protein kinase and nuclear translocation of NF-кB p65 induced by PA (Kwon et al., 2014). It also stimulated adenosine triphosphate (ATP) production, decreased mitochondrial superoxide generation, increased triglyceride and blocked PA-induced diacylglycerol accumulation, with the involvement of protein kinase $\mathrm{A}$ and peroxisome proliferator-activated receptor gamma coactivator-1 $\alpha$ (Kwon et al., 2014). In addition to its neuroprotective effect, OA was found to be synthesised and released by astrocytes 
391 with the stimulation of albumin (Tabernero et al., 2001), Released OA was then incorporated

392 into neurons for the synthesis of phospholipids, and stimulated neuronal differentiation by

393 promoting axonal growth, neuronal clustering and expression of axonal growth-associated

394 protein-43 (Tabernero et al., 2001). The neurotrophic effect of OA involved the binding to its

395 receptor peroxisome proliferator-activated receptor- $\alpha$ (Bento-Abreu et al., 2007)

396

397 The same cytotoxic effect was also observed in the astrocytic cell line, T98G. This PA-induced 398 cytotoxicity was also reported previously in primary cultured mouse astrocytes (Wang et al., 399 2012) and rat cortical astrocytes (Wong et al., 2014). Wang et al. (2012) showed that PA-induced 400 apoptosis in primary mouse astrocytes involved the rise in Bax/Bcl-2 ratio and caspase-3 401 activation. It involved ROS generation and subsequent mitochondrial membrane potential 402 collapse (Wang et al., 2012; Wong et al., 2014). PA was also found to induce inflammatory 403 response in astrocytes via Toll-like receptor 4, by releasing pro-inflammatory cytokines like 404 tumour necrosis factor- $\alpha$ and interleukin-6 (Gupta et al., 2012). The inflammatory response was 405 also observed with the treatment of other SFAs, namely, LA and stearic acid, but not unsaturated 406 FAs (like OA) (Gupta et al., 2012).

408 PA induced cytotoxicity in both SH-SY5Y and SH-SY5Y- $\gamma$, albeit to a lesser extent in the latter, 409 as indicated by the higher $\mathrm{LC}_{50}$. As a marker of cancer progression, overexpression of $\gamma$-syn in 410 ovarian cancer cell lines, A2780 and OVCAR5, was found to enhance tumorigenicity 411 by constitutively activating Extracellular Signal-regulated Kinase-1/2 and down-regulating c-Jun

412 N-terminal kinase 1 in response to a host of environmental stress signals (Pan et al., 2002). In 413 human breast cancer cell lines T47D and SKBR3, knockdown of $\gamma$-syn sensitized the cells to ER 
414 stress-induced apoptosis dependent on c-Jun N-terminal kinases or caspase-3 and caspase-7 415 activation (Hua et al., 2009). Consistent with these, our study suggests an anti-apoptotic role of $416 \gamma$-syn in response to PA-induced cytotoxicity, since the two cells lines used are cancer cell lines. T98G cells after PA treatment. Previously, Da Costa et al. (2000) reported that wt $\alpha$-syn, but not A53T, had anti-apoptotic effect against staurosporine, etoposide and ceramide $\mathrm{C}$ in murine neuronal cell line TSM1. Similarly, our group reported that only wt $\alpha$-syn, but not the mutant variants, protected SH-SY5Y from the toxicity of rotenone and maneb (Parkinsonian pesticides), by attenuating mitochondrial membrane potential changes and ROS level (Choong \& Say, 2011). On the other hand, overexpression of $\alpha$-syn led to oxidative stress-mediated apoptotic death in U373 astrocytoma cells (Stefanova et al., 2001). In this study, we found that transient overexpression of not only wt, but also A30P, E46K $\alpha$-syn and $\gamma$-syn, were able to ameliorate 427 (albeit modestly) PA-induced cytotoxicity in SH-SY5Y and T98G cells. The discrepancy in the cytotoxic effect of $\alpha$-syn overexpression might be due to the transfection method used (transient in this study vs. stable in Stefanova et al., 2001). A further confirmatory study involving stable overexpression of $\alpha$-syn and its PD mutants in SH-SY5Y and T98G cells is needed to further elucidate whether $\alpha$-syn protects against PA-induced cytotoxicity, since $\alpha$-syn has been shown to bind to the surface of triglyceride-rich lipid droplets and protects them from hydrolysis in cultured cells as well as in primary neurons (Cole et al., 2002).

The co-treatment of PA and PQ brought about intensified cytotoxicity in SH-SY5Y cells as 436 compared to PA or PQ treatment alone. There is no previous study reporting on the interaction 
437 between PA and PQ in dopaminergic neurotoxicity, but rotenone, another Parkinsonian 438 environmental toxin which inhibits mitochondrial complex I, was found to increase the 439 incorporation of radioactively-labeled PA into acetyl coA by $\beta$-oxidation in SH-SY5Y cells 440 (Worth et al., 2014). In bovine cerebral mitochondria, PQ was reduced to the PQ radical via 441 complex I in mitochondria, leading to accelerated lipid peroxidation, an effect similar to that 442 triggered by rotenone (Fukushima et al., 1995). It is predicted that the PQ-induced lipid 443 peroxidation is further enhanced by PA, which serves as a substrate for carnitine 444 palmitoyltransferase-1-dependent mitochondrial $\beta$-oxidation, a process that leads to enhanced 445 ROS production (Magtanong et al., 2016). In addition, PA treatment also triggers mitogen446 activated protein kinase- and caspase-dependent signaling pathways leading to apoptosis in 447 neuronal N2a cells (Kwon et al., 2014). PQ was found to trigger SH-SY5Y neuronal cell 448 apoptosis via the intrinsic mitochondrial pathway by the upregulation of p53 protein and 449 subsequently, its target pro-apoptotic Bax protein (Yang and Tiffany-Castiglioni, 2008). The 450 impairment of mitochondria complex I activity was followed by the release of cytochrome $c$, 451 increased caspases 9 and 3 activities, nuclear condensation and DNA fragmentation (Yang \& 452 Tiffany-Castiglioni, 2008). Thus, it is suggested that PQ and PA synergistically enhance SH453 SY5Y cytotoxicity.

454

Leptin, secreted primarily by adipocytes, is transported across the blood-brain barrier and acts on

456 leptin receptors in CNS to regulate food intake by modulating activity of appetite control neurons 457 in the brain (Zhang et al., 1994). Obesity is associated with leptin resistance, where high plasma 458 leptin concentration was observed in most obese humans and rodents but this hyperleptinemia 459 may not reduce appetite or increase energy expenditure (Frederich et al., 1995; Considine et al., 
460 1996). It was reported that leptin receptors, the long and the short isoforms, are expressed in SH461 SY5Y (Russo et al., 2004). However, in this study, pre-treatment of leptin was found to exert no 462 neuroprotective effect against PA-induced cell death in SH-SY5Y cells. In a previous study, 463 leptin was found to stimulate cell proliferation in a dose- and time-dependent manner involving 464 the mechanism of apoptosis suppression in SH-SY5Y cells (Russo et al., 2004). SFAs (including 465 PA) were shown to induce ER stress and inflammatory response via toll-like receptor 4 466 signalling, leading to leptin resistance in rat hypothalamus, whereas rats fed with 467 monounsaturated FAs (including OA) did not develop hypothalamic leptin resistance (Milanski 468 et al., 2009). Therefore, the result suggests a PA-induced leptin resistance in neurons, 469 diminishing its neuroprotective effect.

471 The apoptotic cell death was confirmed with flow cytometric analysis using annexin V/PI 472 staining and cell cycle analysis. The results are consistent with previous studies (Wang et al., 473 2012; Hsiao et al., 2014). In SH-SY5Y, PA induced neuron cell cycle $\mathrm{G}_{2} / \mathrm{M}$ arrest at $24 \mathrm{~h}$ and 474 increased in sub- $\mathrm{G}_{0}$ phase at $48 \mathrm{~h}$ (Hsiao et al., 2014). However, the percentage of apoptotic cells 475 in T98G as quantified by flow cytometry was much lower than that in SH-SY5Y, despite the 476 similar $\mathrm{LC}_{50}$ obtained from the MTT assay. This indicates that the use of MTT assay has a 477 limitation, as its rate of tetrazolium reduction may reflect the general metabolic activity or the 478 rate of glycolytic NADH production, and not the cell number (Berridge et al., 2005). The lesser 479 PA-induced apoptotic cells observed in astrocytic T98G as compared to neuronal SH-SY5Y cells 480 was not in the odd, owing to the high FA $\beta$-oxidation rate in astrocytes as compared to the poor 481 utilisation of FA as fuel in neurons, as discussed earlier (Schönfeld and Reiser, 2013). 
483 In both cell lines, PA and OA treatments were shown to induce ROS generation in a dose484 dependent manner. However, the increase in ROS level was found to be higher in T98G than in 485 SH-SY5Y. Also, the degree of lipid peroxidation was higher in T98G cells as compared to that in $486 \mathrm{SH}-\mathrm{SY} 5 \mathrm{Y}$ cells. However, there is a similar pattern of increment at $100 \mu \mathrm{M}$ PA, decrement at $487200 \mu \mathrm{M}$ and rise again at $300 \mu \mathrm{M}$ in both cell lines, except for the $48 \mathrm{~h}$ treatment in SH-SY5Y. 488 At $48 \mathrm{~h}$, the fold change in lipid peroxidation degree gradually decreased with increasing PA 489 concentrations in SH-SY5Y. These observations may be attributed by the high FA $\beta$-oxidation 490 rate in astrocytes, a prominent source of ROS generation (Seifert et al., 2010; Rodrigues and 491 Gomes, 2012). $\beta$-oxidation of PA yields 15 molecules of flavin adenine dinucleotide $\left(\mathrm{FADH}_{2}\right)$ 492 and 31 molecules of nicotinamide adenine dinucleotide (NADH) $\left(\mathrm{FADH}_{2} / \mathrm{NADH}\right.$ ratio $\left.\approx 0.5\right)$ as 493 compared to that of glucose degradation in which 2 molecules of $\mathrm{FADH}_{2}$ and 10 molecules of $494 \mathrm{NADH}$ are generated $\left(\mathrm{FADH}_{2} / \mathrm{NADH}\right.$ ratio $\left.=0.2\right)($ Schönfeld \& Reiser, 2013). Enhanced ROS 495 generation is observed during the oxidation of $\mathrm{FADH}_{2}$ for ATP generation by the electron 496 transfer flavoprotein-ubiquinone oxidoreductase. Thus, the higher $\mathrm{FADH}_{2} / \mathrm{NADH}$ ratio of $\mathrm{PA} \beta$ 497 oxidation in astrocytes would result in elevated ROS level. On the other hand, OA treatment in 498 both cell lines was also shown to increase the ROS level, despite no cytotoxicity effect was detected by MTT assay. This is not unexpected, as OA was found to induce the production of 500 ROS in rat aortic smooth muscle cells (Lu et al., 1998), human neutrophil (Carrillo et al., 2011) 501 and cultured endothelial cells (bEnd.3) (Gremmels et al., 2015).

502

503

\section{Conclusions}

504 In summary, PA, but not OA and LA, induced cytotoxicity in SH-SY5Y, SH-SY5Y- $\gamma$ and T98G 505 cell lines in a time- and dose-dependent manner. The PA-induced cytotoxicity was found to be 
506 lower in SH-SY5Y- $\gamma$, suggesting its possible role in neuroprotection. Co-treatment of PA and PQ 507 revealed that the PA-induced cytotoxicity was exacerbated by PQ. Leptin did not protect SH508 SY5Y cell line from PA-induced neurotoxicity, suggesting a PA-induced leptin resistance. 509 Annexin V/PI and sub-G $\mathrm{G}_{0}$ cell cycle analysis by flow cytometry revealed that PA-induced 510 apoptotic cell death in both SH-SY5Y and T98G cell lines, but the percentage of apoptosis was 511 much lower in T98G with similar concentrations of PA treatment. This indicates that neurons are 512 more susceptible to PA-induced cytotoxicity. The PA-induced apoptotic cell death was found to 513 be associated with increased lipid peroxidation and ROS generation. Taken together, the results 514 suggest that HFD may cause neuronal and astrocytic damage, which indirectly proposes that 515 CNS pathologies involving neuroinflammation and reactive gliosis could be prevented via the 516 diet regimen. Apart from that, the signalling pathways involved in PA-induced apoptotic cell 517 death and the neuroprotection of $\gamma$-syn warrant further investigation.

\section{References}

Argente-arizón P, Freire-regatillo A, Argente J, Chowen JA. (2015). Role of non-neuronal cells in body weight and appetite control. Front Endocrinol (Lausanne). 6:42.

Avila Rodriguez M, Garcia-Segura LM, Cabezas R, Torrente D, Capani F, Gonzalez J, Barreto GE. (2014). Tibolone protects T98G cells from glucose deprivation. J Steroid Biochem Mol Biol. 144(Pt B):294-303.

Avila-Rodriguez M, Garcia-Segura LM, Hidalgo-Lanussa O, Baez E, Gonzalez J, Barreto GE. (2016). Tibolone protects astrocytic cells from glucose deprivation through a mechanism involving estrogen receptor beta and the upregulation of neuroglobin expression. Mol Cell Endocrinol. 433:35-46. 
529 Bento-Abreu A, Tabernero A, Medina JM. (2007). Peroxisome proliferator-activated receptor-

530 alpha is required for the neurotrophic effect of oleic acid in neurons. J Neurochem. 103:871-81.

532

533

Berridge MV, Herst PM, Tan AS. (2005). Tetrazolium dyes as tools in cell biology: new insights into their cellular reduction. Biotechnol Annu Rev. 11:127-52.

Braak H, Sastre M, Del Tredici K. (2007). Development of alpha-synuclein immunoreactive astrocytes in the forebrain parallels stages of intraneuronal pathology in sporadic Parkinson's disease. Acta Neuropathol. 114:231-41.

Buckman LB, Thompson MM, Moreno HN, Ellacott KL. (2013). Regional astrogliosis in the mouse hypothalamus in response to obesity. J Comp Neurol. 521(6):1322-33.

Cabezas R, Avila MF, Gonzalez J, El-Bacha RS, Barreto GE. (2015). PDGF-BB protects mitochondria from rotenone in T98G cells. Neurotox Res. 27:355-367.

Carrillo, C. Del Mar Cavia M, Roelofs H, Wanten G, Alonso-Torre SR. (2011). Activation of human neutrophils by oleic acid involves the production of reactive oxygen species and a rise in cytosolic calcium concentration: a comparison with N-6 polyunsaturated fatty acids. Cell Physiol Biochem. 28:329-38.

Choong CJ, Say YH. (2011). Neuroprotection of alpha-synuclein under acute and chronic rotenone and maneb treatment is abolished by its familial Parkinson's disease mutations A30P, A53T and E46K. NeuroToxicol. 32:857-63.

Cole NB, Murphy DD, Grider T, Rueter S, Brasaemle D, Nussbaum RL. (2002). Lipid droplet binding and oligomerization properties of the Parkinson's disease protein $\alpha$-synuclein. J Biol Chem. 277:6344-52.

Considine RV, Sinha MK, Heiman ML, Kriauciunas A, Stephens TW, Nyce MR, Ohannesian JP, 
552

553

554

555

556

557

558

559

560

561

562

563

564

565

566

567

568

569

570

571

572

573

574

Marco CC, McKee LJ, Bauer TL, Caro JF. (1996). Serum immunoreactive-leptin concentrations in normal-weight and obese humans. N Engl J Med. 334:292-5.

Da Costa CA, Ancolio K, Checler F. (2000). Wild-type but not Parkinson's disease-related Ala$53 \rightarrow$ Thr mutant $\alpha$-Synuclein protects neuronal cells from apoptotic stimuli. J Biol Chem. 275:24065-9.

Dorfman MD, Thaler JP. (2015). Hypothalamic inflammation and gliosis in obesity. Curr Opin Endocrinol Diabetes Obes. 22:325-30.

Fabelo N, Martín V, Santpere G, Marín R, Torrent L, Ferrer I, Díaz M. (2011). Severe alterations in lipid composition of frontal cortex lipid rafts from Parkinson's disease and incidental Parkinson's disease. Mol Med. 17:1107-18.

Fraser T, Tayler H, Love S. (2010). Fatty acid composition of frontal, temporal and parietal neocortex in the normal human brain and in Alzheimer's disease. Neurochem Res. $35: 503-13$.

Frederich RC, Hamann A, Anderson S, Löllmann B, Lowell BB, Flier JS. (1995). Leptin levels reflect body lipid-content in mice: evidence for diet-induced resistance to leptin action. Nat Med. 1:1311-4.

Freire-Regatillo A, Argente-Arizón P, Argente J, García-Segura LM, Chowen JA. (2017). Nonneuronal cells in the hypothalamic adaptation to metabolic signals. Front Endocrinol (Lausanne). 8:51.

Fukushima T, Tawara T, Isobe A, Hojo N, Shiwaku K, Yamane Y. 1995. Radical formation site of cerebral complex I and Parkinson's disease. J Neurosci Res. 42:385-90.

Golovko MY, Faergeman NJ, Cole NB, Castagnet PI, Nussbaum RL, Murphy EJ. (2005). $\alpha$ synuclein gene deletion decreases brain palmitate uptake and alters the palmitate 
metabolism in the absence of a-synuclein palmitate binding. Biochemistry. 44:8251-9.

576 Gremmels H, Bevers LM, Fledderus JO, Braam B, van Zonneveld AJ, Verhaar MC, Joles JA.

577

578

579

580

581

582

583

584

585

586

587

588

589

590

591

592

593

594

595

596

597

(2015). Oleic acid increases mitochondrial reactive oxygen species production and decreases endothelial nitric oxide synthase activity in cultured endothelial cells. Eur J Pharmacol. 751:67-72.

Guest J, Garg M, Bilgin A, Grant, R. (2013). Relationship between central and peripheral fatty acids in humans. Lipids Health Dis. 12:79.

Guillemot-Legris O, Muccioli GG. (2017). Obesity-induced neuroinflammation: beyond the hypothalamus. Trends in Neurosci. 40:237-53.

Gunstone FD, Harwood JL, Dijkstra AJ. (2010). The lipid handbook with CD-ROM. CRC Press: Boca Raton, FL, USA.

Gupta S, Knight AG, Gupta S, Keller JN, Bruce-Keller AJ. (2012). Saturated long-chain fatty acids activate inflammatory signaling in astrocytes. J Neurochem. 120:1060-71.

Gustafson D, Rothenberg E, Blennow K, Steen B, Skoog I. (2003). An 18-year follow-up of overweight and risk of Alzheimer disease. Arch Intern Med. 163:1524-8.

Henry CM, Hollville E, Martin SJ (2013). Measuring apoptosis by microscopy and flow cytometry. Methods. 61:90-7.

Hsiao J-H, Halliday GM, Kim WS. (2017). $\alpha$-synuclein regulates neuronal cholesterol efflux. Molecules. 22:1769.

Hsiao YH, Lin CI, Liao H, Chen YH, Lin SH. (2014). Palmitic acid-induced neuron cell cycle G2/M arrest and endoplasmic reticular stress through protein palmitoylation in SH-SY5Y human neuroblastoma cells. Int J Mol Sci.15:20876-99.

Hu G, Jousilahti P, Nissinen A, Antikainen R, Kivipelto M, Tuomilehto J. (2006). Body mass 
index and the risk of Parkinson disease. Neurology. 67:1955-9.

599 Hua H, Xu L, Wang J, Jing J, Luo T, Jiang Y. (2009). Up-regulation of gamma-synuclein

600 contributes to cancer cell survival under endoplasmic reticulum stress. J Pathol. 217:507-

601 515.

602

603

604

605

606

607

608

609

610

611

612

613

614

615

616

617

618

619

620

Karmi A, Iozzo P, Viljanen A, Hirvonen J, Fielding BA, Virtanen K, Oikonen V, Kemppainen J, Viljanen T, Guiducci L, Haaparanta-Solin M, Någren K, Solin O, Nuutila P. (2010). Increased brain fatty acid uptake in metabolic syndrome. Diabetes. 59:2171-7.

Kim J, Park Y-J, Jang Y, Kwon YH. (2011). AMPK activation inhibits apoptosis and tau hyperphosphorylation mediated by palmitate in SH-SY5Y cells. Brain Res. 1418:42-51.

Kwon B, Lee H-K, Querfurth HW. (2014). Oleate prevents palmitate-induced mitochondrial dysfunction, insulin resistance and inflammatory signaling in neuronal cells. Biochim Biophys Acta. 1843:1402-13.

Logroscino G, Marder K, Cote L, Tang MX, Shea S, Mayeux R. (1996). Dietary lipids and antioxidants in Parkinson's disease: a population-based, case-control study. Ann Neurol. 39:89-94.

Lu G, Greene EL, Nagai T, Egan BM. (1998). Reactive oxygen species are critical in the oleic acid-mediated mitogenic signaling pathway in vascular smooth muscle cells. Hypertension. 32:1003-10.

Lu J, Park CS, Lee SK, Shin DW, Kang JH. (2006). Leptin inhibits 1-methyl-4phenylpyridinium-induced cell death in SH-SY5Y cells. Neurosci Lett. 407:240-3.

Magtanong L, Ko PJ, Dixon SJ. (2016). Emerging roles for lipids in non-apoptotic cell death. Cell Death Diff. 23:1099-109.

Milanski M, Degasperi G, Coope A, Morari J, Denis R, Cintra DE, Tsukumo DM, Anhe G, 
621

622

623

624

625

626

627

628

629

630

631

632

633

634

635

636

637

638

639

640

641

642

643

Amaral ME, Takahashi HK, Curi R, Oliveira HC, Carvalheira JB, Bordin S, Saad MJ, Velloso LA. (2009). Saturated fatty acids produce an inflammatory response predominantly through the activation of TLR4 signaling in hypothalamus: implications for the pathogenesis of obesity. J Neurosci. 29:359-70.

Millership S, Ninkina N, Rochford JJ, Buchman VL. (2013). $\gamma$-synuclein is a novel player in the control of body lipid metabolism. Adipocyte 2:276-80.

Murphy MG, Jollimore C, Crocker JFS, Her H. (1992). B-Oxidation of [114C]palmitic acid by mouse astrocytes in primary culture: effects of agents implicated in the encephalopathy of Reye's syndrome. J. Neurosci. Res. 33:445-54.

Pan ZZ, Bruening W, Giasson BI, Lee VM-Y, Godwin AK.. (2002). $\gamma$-synuclein promotes cancer cell survival and inhibits stress- and chemotherapy drug-induced apoptosis by modulating MAPK pathways. J Biol Chem. 277:35050-60.

Park HR, Kim J-Y, Park K-Y, Lee J. (2011). Lipotoxicity of palmitic acid on neural progenitor cells and hippocampal neurogenesis. Toxicol Res. 27:103-10.

Pezzoli G, Cereda E. (2013). Exposure to pesticides or solvents and risk of Parkinson disease. Neurology 80:2035-41.

Polymeropoulos MH, Lavedan C, Leroy E, Ide SE, Dehejia A, Dutra A, Pike B, Root H, Rubenstein J, Boyer R, Stenroos ES, Chandrasekharappa S, Athanassiadou A, Papapetropoulos T, Johnson WG, Lazzarini AM, Duvoisin RC, Di Iorio G, Golbe LI, Nussbaum RL. (1997). Mutation in the $\alpha$-synuclein gene identified in families with Parkinson's disease. Science. 276:2045-7.

Rodrigues JV, Gomes CM. (2012). Mechanism of superoxide and hydrogen peroxide generation by human electron-transfer flavoprotein and pathological variants. Free Radic Biol Med. 
645

646

647

648

649

650

651

652

653

654

655

656

657

658

659

660

661

662

663

664

665

666

Russo VC, Metaxas S, Kobayashi K, Harris M, Werther GA. (2004). Antiapoptotic effects of leptin in human neuroblastoma cells. Endocrinology. 145:4103-12.

Sääksjärvi K, Knekt P, Männistö S, Lyytinen J, Jääskeläinen T, Kanerva N, Heliövaara M. (2014). Reduced risk of Parkinson's disease associated with lower body mass index and heavy leisure-time physical activity. Eur J Epidemiol. 29:285-92.

Schönfeld P, Reiser G. (2013). Why does brain metabolism not favor burning of fatty acids to provide energy? - Reflections on disadvantages of the use of free fatty acids as fuel for brain. J Cereb Blood Flow Metab. 33:1493-9.

Seifert EL, Estey C, Xuan JY, Harper ME. (2010). Electron transport chain-dependent and independent mechanisms of mitochondrial $\mathrm{H} 2 \mathrm{O} 2$ emission during long-chain fatty acid oxidation. J Biol Chem. 285:5748-58.

Spillantini MG, Goedert M. (2000). The alpha-synucleinopathies: Parkinson's disease, dementia with Lewy bodies, and multiple system atrophy. Ann N Y Acad Sci. 920:16-27.

Stefanova N, Klimaschewski L, Poewe W, Wenning GK, Reindl M. (2001). Glial cell death induced by overexpression of alpha-synuclein. J Neurosci Res. 65:432-8.

Tabernero A, Lavado EM, Granda B, Velasco A, Medina JM. (2001). Neuronal differentiation is triggered by oleic acid synthesized and released by astrocytes. J Neurochem. 79:606-16.

Wakabayashi K, Hayashi S, Yoshimoto M, Kudo H, Takahashi H. (2000). NACP/alphasynuclein-positive filamentous inclusions in astrocytes and oligodendrocytes of Parkinson's disease brains. Acta Neuropathol. 99:14-20.

Wang Z, Liu D, Wang J, Liu S, Gao M, Ling EA, Hao A. (2012). Cytoprotective effects of melatonin on astroglial cells subjected to palmitic acid treatment in vitro. J Pineal Res. 
667

668

669

670

671

672

673

674

675

676

677

678

679

680

681

682

683

684

685

686

687

688

689

52:253-64.

Weng Z, Signore AP, Gao Y, Wang S, Zhang F, Hastings T, Yin XM, Chen J. (2007). Leptin protects against 6-hydroxydopamine-induced dopaminergic cell death via mitogenactivated protein kinase signaling. J Biol Chem. 282:34479-91.

Wong KL, Wu YR, Cheng KS, Chan P, Cheung CW, Lu DY, Su TH, Liu ZM, Leung YM. (2014). Palmitic acid-induced lipotoxicity and protection by $(+)$-catechin in rat cortical astrocytes. Pharmacol Rep. 66:1106-13.

World Health Organization. (2018). Obesity and overweight [Online]. Available at: http://www.who.int/mediacentre/factsheets/fs311/en/ [Accessed: 26 February 2018].

Worth AJ, Basu SS, Snyder NW, Mesaros C, Blair IA. (2014). Inhibition of neuronal cell mitochondrial complex $\mathrm{i}$ with rotenone increases lipid $\beta$-oxidation, supporting acetylcoenzyme a levels. J Biol Chem. 289:26895-903.

Xie HR, Hu LS, Li GY. (2010). SH-SY5Y human neuroblastoma cell line: in vitro cell model of dopaminergic neurons in Parkinson's disease. Chin Med J (Engl). 123:1086-92.

Yang W, Tiffany-Castiglioni E. (2008). Paraquat-induced apoptosis in human neuroblastoma SH-SY5Y cells: involvement of p53 and mitochondria. J Toxicol Environ Health A. 71:289-99.

Yuan Q, Zhao S, Wang F, Zhang H, Chen ZJ, Wang J, Wang Z, Du Z, Ling EA, Liu Q, Hao A. (2013). Palmitic acid increases apoptosis of neural stem cells via activating c-Jun Nterminal kinase. Stem Cell Res. 10:257-66.

Zhang L, Ji J, Zhu XY, Wu YY, Yu H, Zhang B, Li XL, Sun XZ. (2004). Palmitic acid induces apoptosis in human hepatoma cell line, HepG2 cells. Zhongguo Yi Xue Ke Xue Yuan Xue Bao. 26:671-6. 
690

691

692

693

694

695

696

697

698

699

700

701

702

703

704

705

706

707

708

709

710

711

712
Zhang Y, Proenca R, Maffei M, Barone M, Leopold L, Friedman JM. (1994). Positional cloning of the mouse obese gene and its human homologue. Nature. 372:425-32.

\section{Figure legends}

Figure 1: PA, but not OA or LA, is neurotoxic and gliatoxic to SH-SY5Y and T98G cells, and the effects are ameliorated by $\gamma$-syn overexpression and exacerbated by PQ treatment.

SH-SY5Y and SH-SY5Y- $\gamma$ cells were treated with increasing concentrations of PA $(\mathbf{A}, \mathbf{B}), \mathrm{OA}$ (C, D) and LA (E, F) for $24 \mathrm{~h}(\mathbf{A}, \mathbf{C}, \mathbf{E})$ or $48 \mathrm{~h}(\mathbf{B}, \mathbf{D}, \mathbf{F})$. Data represent mean \pm S.E.M. of three independent experiments; $\mathrm{a}$ and $\mathrm{b}$ represent $p<0.05$ as compared to the untreated for SHSY5Y and SH-SY5Y- $\gamma$, respectively. G. Effects of fatty acid treatments in T98G cell line. T98G cells were treated with increasing concentrations $(0,100,200,300,400$ and $500 \mu \mathrm{M})$ of PA, OA and LA for $48 \mathrm{~h}$; $\mathrm{a}, \mathrm{b}$ and $\mathrm{c}$ represent $p<0.05$ as compared to the untreated for PA, OA and LA, respectively. H. SH-SY5Y cells were co-treated with $300 \mu \mathrm{M}$ PA and with increasing concentrations $(0,200,400,600$, and $800 \mu \mathrm{M})$ of PQ for $48 \mathrm{~h}$. MTT assay was then performed. Data represent mean \pm S.E.M. of three independent experiments; * represents $p<0.05$ as compared to $300 \mu \mathrm{M}$ of PA treatment. I. SH-SY5Y cells were pre-treated with increasing concentrations $(0,10,20,30,40$ and $50 \mu \mathrm{g} / \mathrm{ml})$ of leptin for $6 \mathrm{~h}$ followed by $300 \mu \mathrm{M}$ PA treatment for $48 \mathrm{~h}$. MTT assay was then performed. Data represent mean \pm S.E.M. of three independent experiments; * represents $p<0.05$ as compared to untreated.

Figure 2: Effects of PA and OA on $\alpha$-syn or $\gamma$-syn transient-transfected SH-SY5Y and T98G cells. SH-SY5Y and T98G cells were transfected with wild type (WT), different mutants of $\alpha$-syn (A30P, E46K and A53T) and $\gamma$-syn for $48 \mathrm{~h}$ followed by the treatment of $300 \mu \mathrm{M}$ of PA 
713 or $100 \mu \mathrm{M}$ OA for $48 \mathrm{~h}$. Then, MTT assay was performed. A. SH-SY5Y. B. T98G. Data

714 represent mean \pm S.E.M. of three independent experiments; * represents $p<0.05$ as compared to

715 the untransfected, untreated.

716

717 Figure 3: Annexin V-Alexa Fluor ${ }^{\circledR}$ 488/PI flow cytometric analysis of apoptosis and cell 718 cycle in SH-SY5Y and T98G cells after $48 \mathrm{~h}$ of PA treatment. SH-SY5Y and T98G cells were 719 treated with increasing concentrations $(0,100,200$ and $300 \mu \mathrm{M})$ of PA for $48 \mathrm{~h}$. Cells were 720 stained with annexin V- Alexa Fluor ${ }^{\circledR} 488$ and PI followed by flow cytometric analysis. 721 Representative dot plots from one experiment are shown. -/+ = necrosis, +/+ = late apoptosis, -/$722=$ live cells and $+/-=$ early apoptosis. A. SH-SY5Y. B. T98G. Cell cycle distribution was also 723 analysed by flow cytometry. Representative DNA content histograms from one experiment were 724 presented. $R 1=$ Sub $-G_{0} / G_{1}$ phase, $R 2=G_{0} / G_{1}$ phase, $R 3=S$ phase and $R 4=G_{2} / M$ phase. C. 725 SH-SY5Y. D. T98G. E. Statistical graph of the '+/- quadrant' of the dot plots of SH-SY5Y and 726 T98G cells. Data represent the mean \pm S.E.M. of three independent experiments. * represents $p<$ 7270.01 as compared to untreated. F. Statistical graph of R1 gate of SH-SY5Y and T98G cells. Data 728 represent the mean \pm S.E.M. of three independent experiments. * represents $p<0.01$ as 729 compared to untreated.

730

731

732

733

Figure 4: Measurement of ROS generation and lipid peroxidation in SH-SY5Y and T98G cells after PA and OA treatment. SH-SY5Y and T98G cells were treated with increasing concentrations $(0,100,200,300,400$ and $500 \mu \mathrm{M})$ of PA or OA for $6 \mathrm{~h}$ and the ROS generation was measured using the DCFH-DA assay. Figure shows the fold change in fluorescent intensity 735 as compared to the untreated group. A. SH-SY5Y.

B. T98G; Data represent the mean \pm S.E.M. 
736 of three independent experiments; * represents $p<0.05$ as compared to the untreated. SH-SY5Y

737 and T98G cells were also treated with increasing concentrations $(0,100,200$ and $300 \mu \mathrm{M})$ of PA

738 for $24 \mathrm{~h}$ or $48 \mathrm{~h}$ and TBARS assay was then performed. C. SH-SY5Y. D. T98G. Data represent

739 the mean \pm S.E.M. of three independent experiments; * represents $p<0.05$ as compared to 740 untreated. 


\section{Figure 1}

PA, but not OA or LA, is neurotoxic and gliatoxic to SH-SY5Y and T98G cells, and the effects are ameliorated by $\gamma$-syn overexpression and exacerbated by $P Q$ treatment

SH-SY5Y and SH-SY5Y-Y cells were treated with increasing concentrations of PA (A, B), OA (C,

D) and $L A(E, F)$ for $24 \mathrm{~h}(A, C, E)$ or $48 \mathrm{~h}(B, D, F)$. Data represent mean \pm S.E.M. of three independent experiments; $a$ and $b$ represent $p<0.05$ as compared to the untreated for $\mathrm{SH}$ SY5Y and SH-SY5Y-Y, respectively. G. Effects of fatty acid treatments in T98G cell line. T98G cells were treated with increasing concentrations $(0,100,200,300,400$ and $500 \mu \mathrm{M})$ of PA, $\mathrm{OA}$ and LA for $48 \mathrm{~h} ; \mathrm{a}, \mathrm{b}$ and $\mathrm{c}$ represent $\mathrm{p}<0.05$ as compared to the untreated for PA, OA and LA, respectively. H. SH-SY5Y cells were co-treated with $300 \mu \mathrm{M} \mathrm{PA}$ and with increasing concentrations $(0,200,400,600$, and $800 \mu \mathrm{M})$ of $\mathrm{PQ}$ for $48 \mathrm{~h}$. MTT assay was then performed. Data represent mean \pm S.E.M. of three independent experiments; * represents $p$ $<0.05$ as compared to $300 \mu \mathrm{M}$ of PA treatment. I. SH-SY5Y cells were pre-treated with increasing concentrations $(0,10,20,30,40$ and $50 \mu \mathrm{g} / \mathrm{ml})$ of leptin for $6 \mathrm{~h}$ followed by 300 $\mu \mathrm{M}$ PA treatment for $48 \mathrm{~h}$. MTT assay was then performed. Data represent mean \pm S.E.M. of three independent experiments; $*$ represents $p<0.05$ as compared to untreated. 


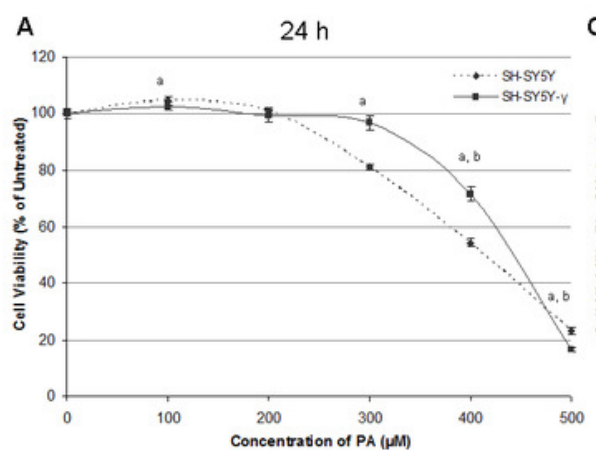

$48 \mathrm{~h}$
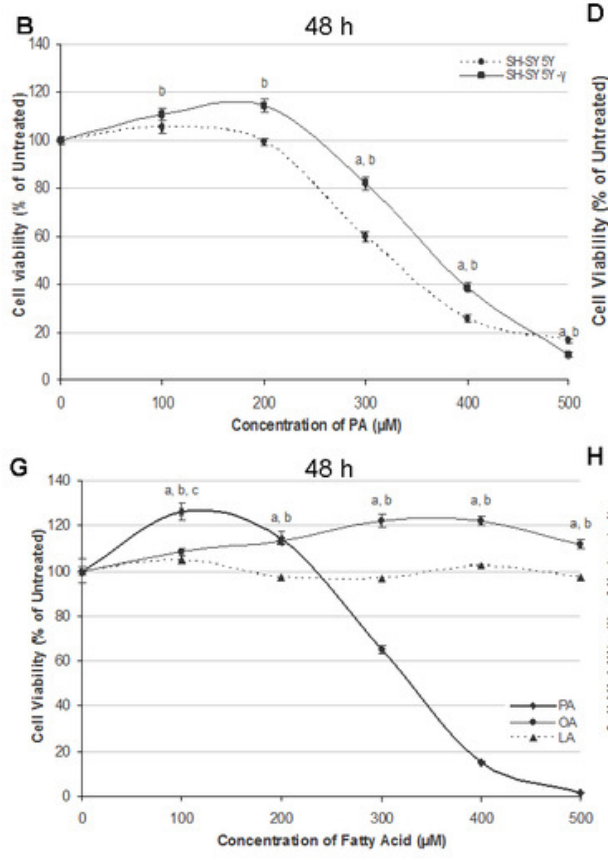

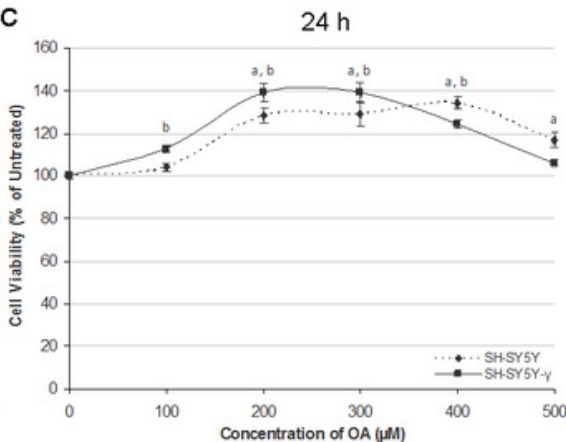

$48 \mathrm{~h}$

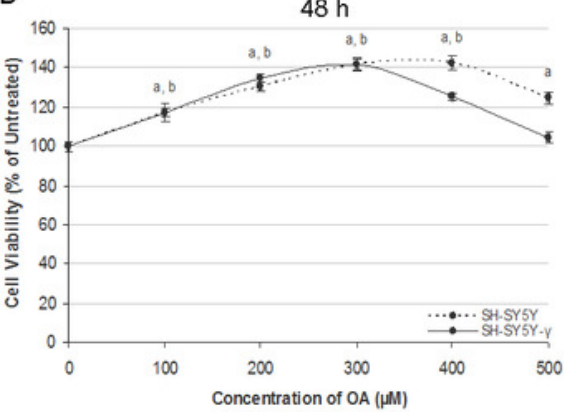

$\mathrm{H}$

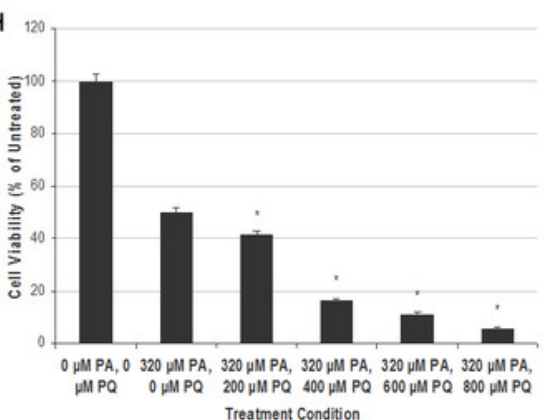

E

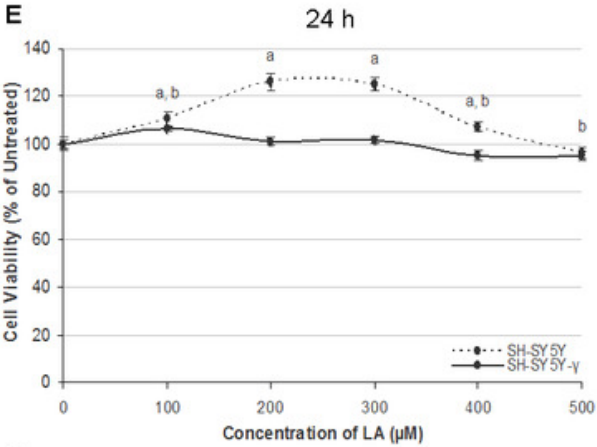

F
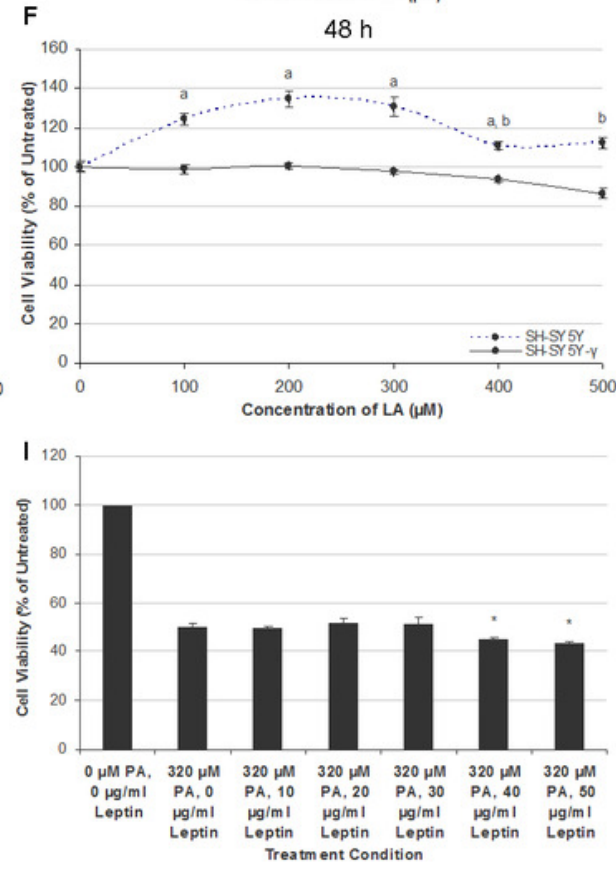


\section{Figure 2}

Effects of PA and OA on $\alpha$-syn or $\gamma$-syn transient-transfected SH-SY5Y and T98G cells

SH-SY5Y and T98G cells were transfected with wild type (WT), different mutants of $\alpha$-syn (A30P, E46K and A53T) and $y$-syn for $48 \mathrm{~h}$ followed by the treatment of $300 \mu \mathrm{M}$ of PA or 100 $\mu \mathrm{M}$ OA for $48 \mathrm{~h}$. Then, MTT assay was performed. A. SH-SY5Y. B. T98G. Data represent mean \pm S.E.M. of three independent experiments; * represents $p<0.05$ as compared to the untransfected, untreated. 

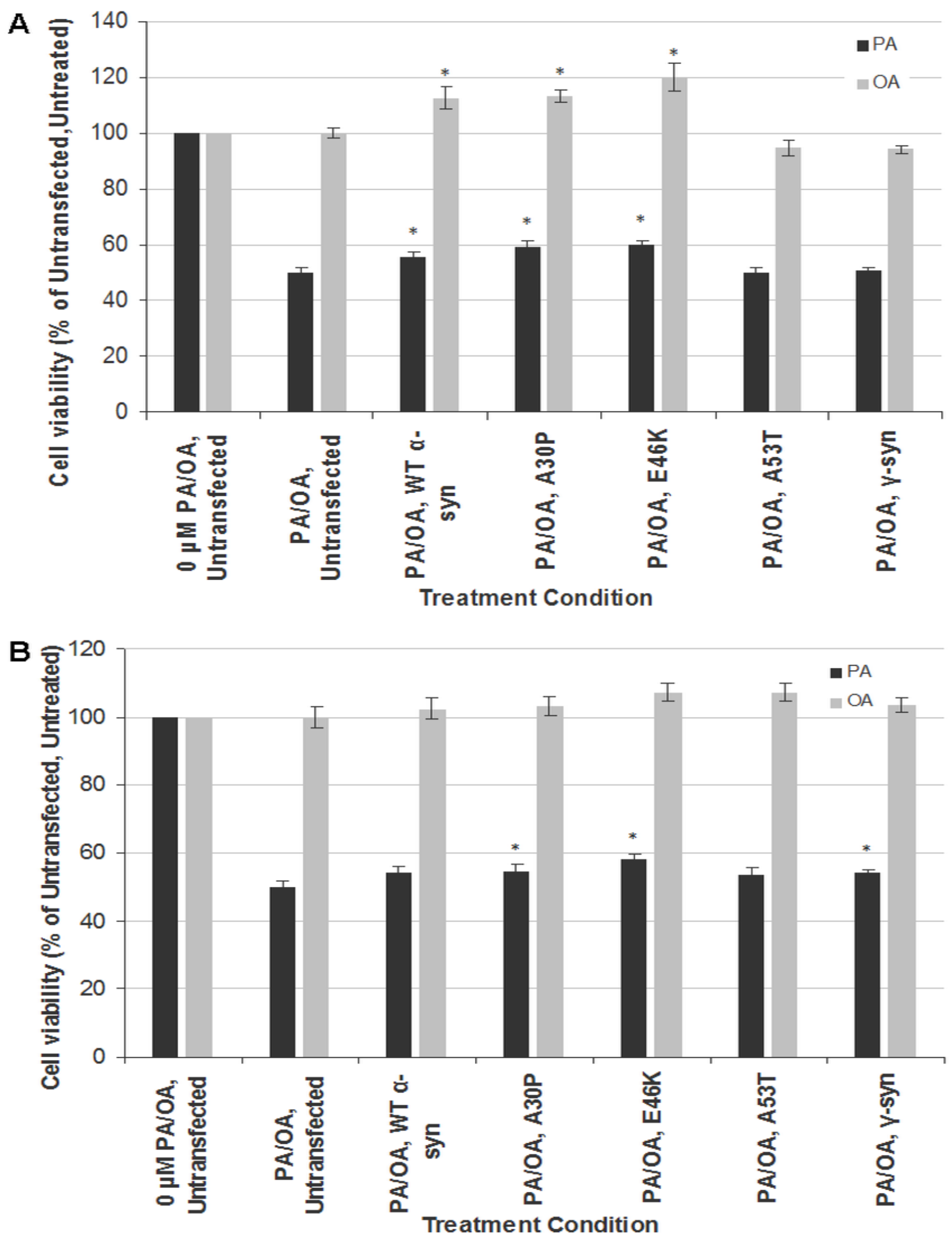


\section{Figure 3}

Annexin V- Alexa Fluor ${ }^{\circledR}$ 488/PI flow cytometric analysis of apoptosis and cell cycle in SH-SY5Y and T98G cells after $48 \mathrm{~h}$ of PA treatment

SH-SY5Y and T98G cells were treated with increasing concentrations $(0,100,200$ and 300 $\mu \mathrm{M})$ of PA for $48 \mathrm{~h}$. Cells were stained with annexin V- Alexa Fluor ${ }^{\circledR} 488$ and PI followed by flow cytometric analysis. Representative dot plots from one experiment are shown. $-/+=$ necrosis, $+/+=$ late apoptosis, $/-=$ live cells and +/- = early apoptosis. A. SH-SY5Y. B. T98G. Cell cycle distribution was also analysed by flow cytometry. Representative DNA content histograms from one experiment were presented. $R 1=$ Sub-G $\neg 0 / G 1$ phase, $R 2=G 0 / G \neg 1$ phase, R3 $=$ S phase and R4 = G2/M phase. C. SH-SY5Y. D. T98G. E. Statistical graph of the '+/- quadrant' of the dot plots of SH-SY5Y and T98G cells. Data represent the mean \pm S.E.M. of three independent experiments. * represents $p<0.01$ as compared to untreated. $F$. Statistical graph of R1 gate of SH-SY5Y and T98G cells. Data represent the mean \pm S.E.M. of three independent experiments. $*$ represents $p<0.01$ as compared to untreated. 


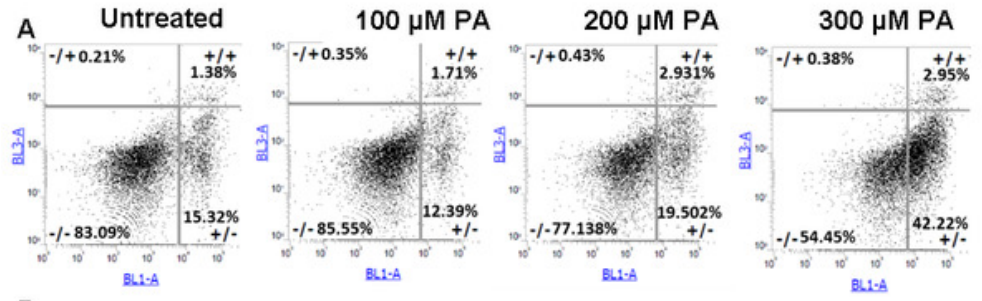

B
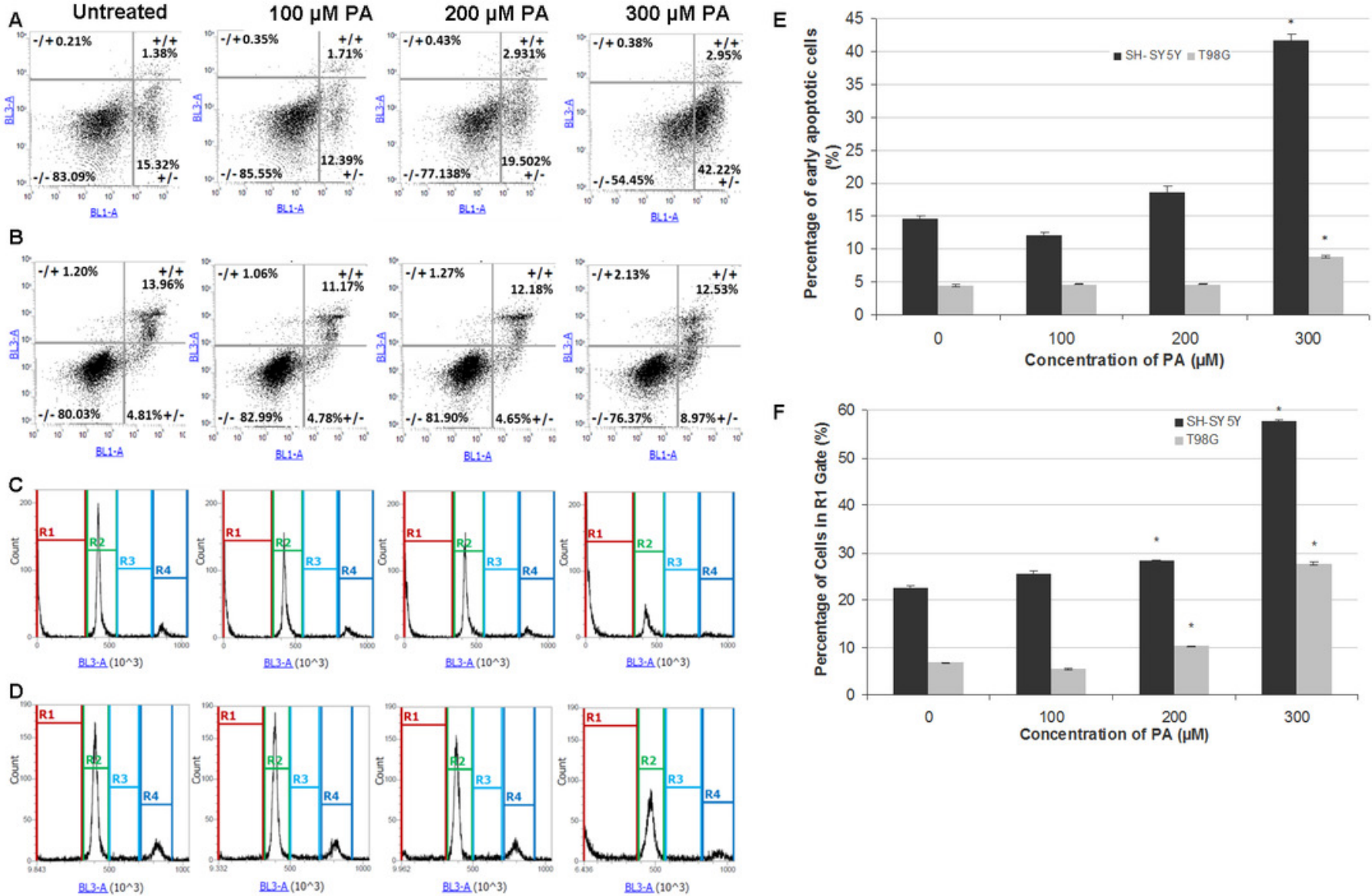


\section{Figure 4}

Measurement of ROS generation and lipid peroxidation in SH-SY5Y and T98G cells after $P A$ and $O A$ treatment

SH-SY5Y and T98G cells were treated with increasing concentrations $(0,100,200,300,400$ and $500 \mu \mathrm{M}$ ) of PA or OA for $6 \mathrm{~h}$ and the ROS generation was measured using the DCFH-DA assay. Figure shows the fold change in fluorescent intensity as compared to the untreated group. A. SH-SY5Y. B. T98G; Data represent the mean \pm S.E.M. of three independent experiments; * represents $p<0.05$ as compared to the untreated. SH-SY5Y and T98G cells were also treated with increasing concentrations $(0,100,200$ and $300 \mu \mathrm{M})$ of PA for $24 \mathrm{~h}$ or $48 \mathrm{~h}$ and TBARS assay was then performed. C. SH-SY5Y. D. T98G. Data represent the mean \pm S.E.M. of three independent experiments; * represents $p<0.05$ as compared to untreated.
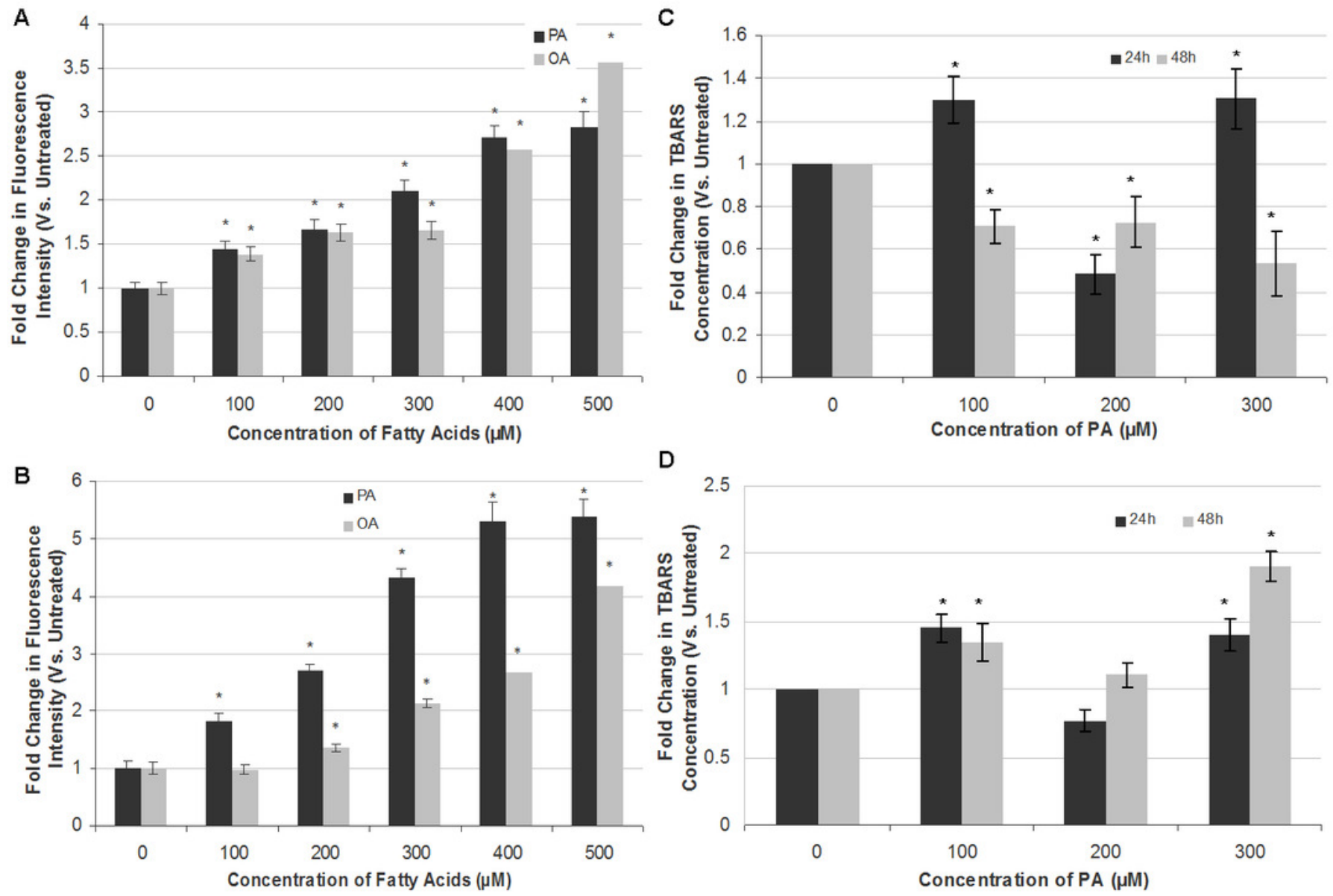

D

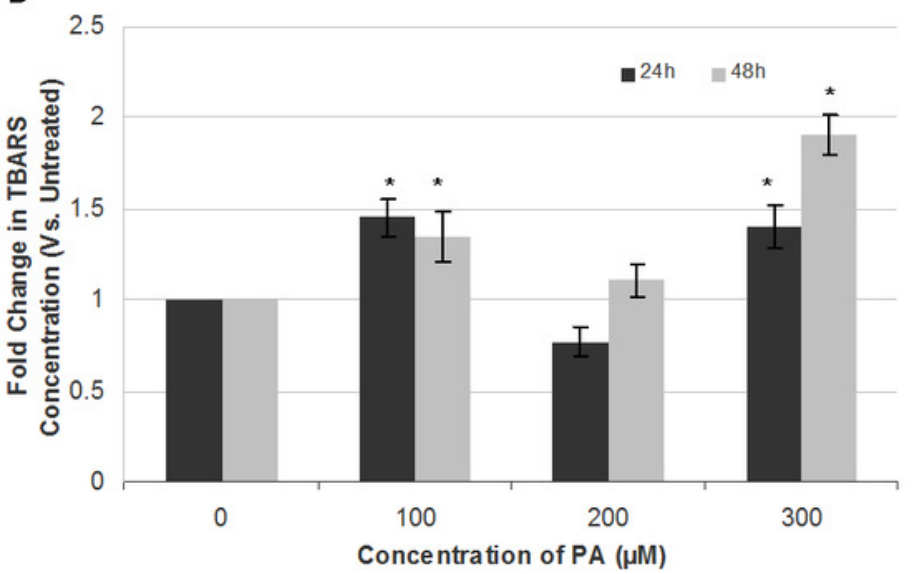

